\title{
5
}

\section{Moving Objects: Reflections on Oceanic Collections}

\author{
Margaret Jolly \\ In memory of Epeli Hau'ofa, Oceanic visionary
}

\section{Prologue}

In a conference dedicated to 'Putting People First' it may seem perverse to deliver an opening keynote talk about 'things'. But, as we all know, in the place we call Oceania the dichotomy between persons and things, subjects and objects is often refused as an imposition of the West, not just in the theory talk of anthropologists (Gell 1998; Strathern 1988; Thomas 1995; see also Paini and Gnecchi-Ruscone, and Pigliasco this volume) but in the quotidian conversations of Pacific people. ${ }^{1}$ Valued objects of human creation are rather animated, embodying the presence of divine gods, ancestors, dead and living persons, sometimes in the midst of swirling

1 I am here of course alluding not just to Marilyn Strathern's hugely influential book The Gender of the Gift (1988), which refuses the dichotomies of persons and things, subjects and objects in Melanesia but to the theory of art developed by Alfred Gell (1998; cf. Thomas 1995) which suggested art was to be found not in beauty but efficacy, and that an art object is an agent intended to change the world; rather than images or idols representing gods they are embodiments of them, 'physical instantiation[s] of divinity' (Hooper 2006: 28). See also the influence of Bruno Latour (1993) in these debates and his discussions of modernity and the work of 'purification' in distinguishing human from nonhuman and agency from natural determinism. Webb Keane (2007) offers a scintillating exploration of cognate problems in the context of mission encounters, in the particular context of Calvinism in Sumba, Eastern Indonesia. 
bodies in indigenous ritual practices, sometimes surrounded by curious spectators in galleries and museums, sometimes lying lonely in the vaults of institutional storage. ${ }^{2}$

In this lecture, I reflect on the aesthetics and the cultural politics of moving objects in Oceanic collections. I consider these objects as 'moving' in three dimensions. First, I look at Oceanic objects as moving in the physical sense, from their origins in Pacific places, across land and ocean, to resting places in museums and galleries within and beyond the region, in Europe, North America and Australia. Second, I ponder the affective responses such objects elicit, how they move living human subjects, variously stimulating curiosity, respect, awe, terror or rage in spectators, some of whom are genealogically connected to the original creators, but most of whom are not. Third, I trace how objects move in the sense of the changing purposes or curatorial contexts of their display between different periods and different places. 'Objects are never static' (Kimmelman 2006: 1); they accumulate the meanings invested in them in different times and places. I too will be moving, between Göttingen, Honolulu and Canberra. But three questions anchor my Oceanic passage.

First, I situate these reflections in earlier conversations about the 'new museum' (see Message 2006). The 'newness' claimed for the new museum is far more than recent creation or renovation. Some suggest that new museums reside in a novel cultural and political terrain, with newly configured, even 'postcolonial', relations between creators, collectors, objects, curators and spectators. These allegedly eclipse the earlier colonial character of Enlightenment knowledge, preoccupied as it was with distantiated classification and presumptuous evolutionary typologies of 'others' and the objects they created. Some consider this has been superseded by more open and dialogical relations of knowing, more interactive collaborations, more egalitarian curatorial postures. This claim bears critical scrutiny in its representation of pasts, presents and futures (see Jolly 2011a; MacDonald 2007).

Second, I ask how far contemporary curatorial practice has transcended the clichéd polarities between aesthetic and ethnographic frames, between art and anthropology, formalism and history? One side vaunts the spotlit isolation of the beautiful object, devoid of distracting captions, ethnographic and historical contextualisation, stunningly 'nude' in the

2 See my review article on Atua: Sacred Gods from Polynesia, an exhibition curated by Michael Gunn at the National Gallery of Australia in 2014 (Jolly 2014). 
words of Stéphane Martin, director of the Musée du Quai Branly (MQB) (Naumann 2006: 122). This approach conceives curatorial work as like making theatre, as a performance art. The other side finds the beauty and potency of objects in ethnographic and historical context, celebrates tougher processes of cultural translation and digs deeper in painful excavation through the colonial sediment which clings to the histories connecting Oceanic objects and human persons. ${ }^{3}$

Third, I consider the relation between the creators, the objects in Oceanic collections and their descendants living in the islands of the Pacific and in the diaspora. At the opening of Musée du Quai Branly in June 2005, Ralph Regenvanu enjoined overseas curators to follow the precedent of the Vanuatu Cultural Centre in its stress on 'living culture' (Clifford 2007), animating objects from the past in relation to contemporary practices and novel artistic traditions. Such calls have been heeded by some institutions. How are museum directors and curators responding to such indigenous calls in Europe as well as that expanded region the late Epeli Hau ofa reimagined and revalorised as Oceania (see Hau'ofa 2008; Jolly 2007a, 2008)?

\section{In Göttingen: The Cook/Forster collection}

The modest cloisters of the Institute of Social and Cultural Anthropology at the Georg-August University of Göttingen is the usual home of about 400 Oceanic objects collected during the three voyages of Captain James Cook. These objects come from diverse Pacific places: Tonga, Tahiti and the Society Islands, Hawai' $i$, the Marquesas, Easter Island (now Rapanui), Aotearoa New Zealand, New Hebrides (now Vanuatu) and New Caledonia, and from Alaska and Tierra del Fuego on the Pacific coasts of North and South America. During the course of the voyages, these Oceanic objects were variously given to or exchanged with Cook, scientists, officers, and crew for nails, iron tools, pins, buttons, beads and cloth, or exchanged for other Oceanic objects earlier collected, such as fine white tapa from Tahiti or red feathers from Tonga. They include objects of daily apparel and use: clothing, ornaments, combs, tattooing tools, fishhooks, bowls, baskets, musical instruments, weapons, barkcloth, sumptuous ritual regalia (see Figure 1)

3 James Clifford (2007) has suggested a truce between these opposing positions in the context of the MQB. To me such a truce, though desirable, seems rather fragile since the ethnographic mode is portrayed by the MQB as old-fashioned and colonial while the aesthetic mode allegedly transcends that past (see also Clifford 2014). But, as Sally Price has argued, seeing such Oceanic objects as 'art' rather than artefact is equally implicated in genealogies of 'primitivism' (2007; see Jolly 2011a for an extended discussion). 
and images of gods. Yet, any distinction between practical use and ritual potency is fraught, since fishhooks, weapons of war, baskets and cloth were often also imbued with divine efficacy (see Hooper 2006: 41, 46).

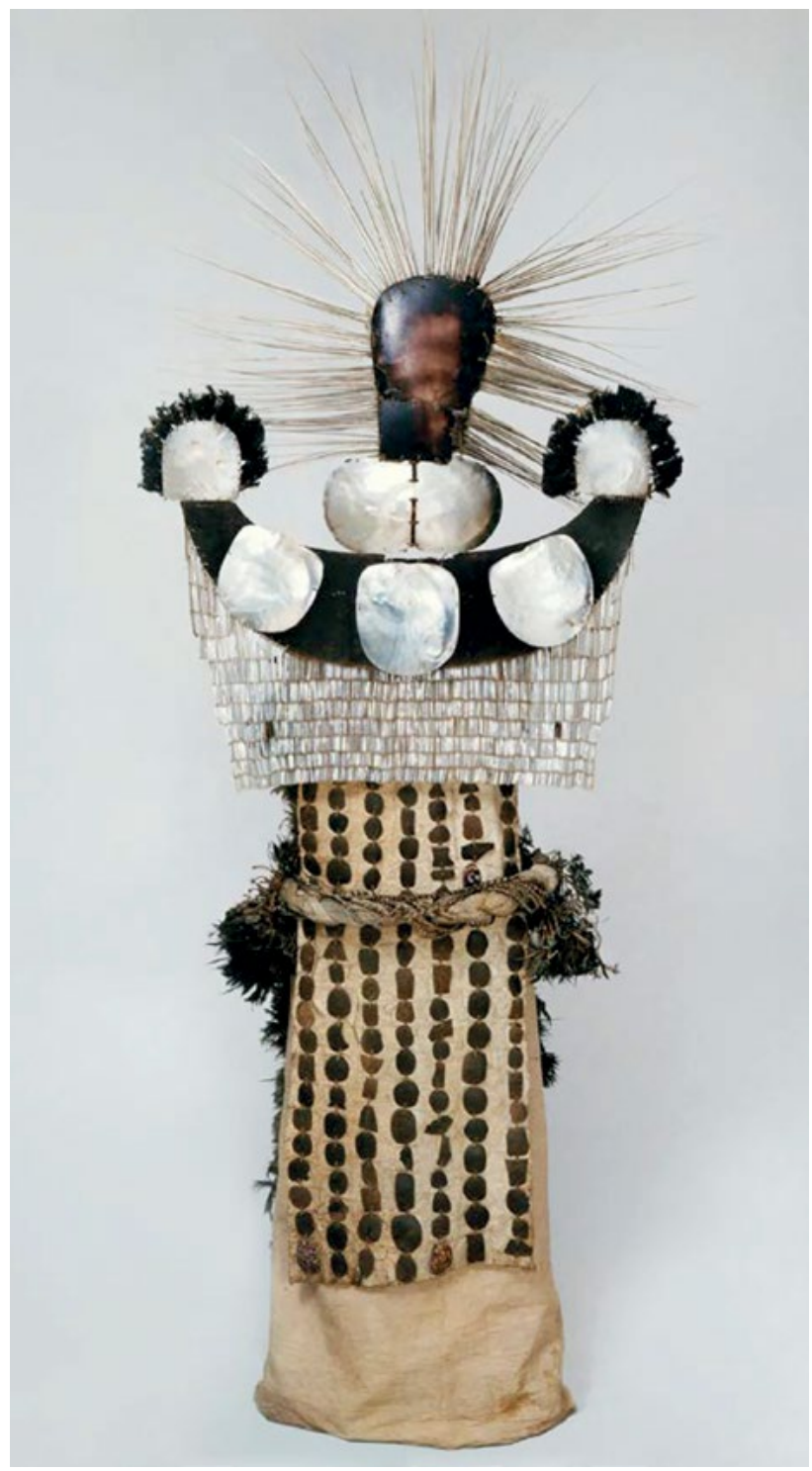

Figure 1. A heva tūpāpa'u, or chief mourner's costume, from the Society Islands

Source. Reproduced courtesy of the National Museum of Australia from Cook's Pacific Encounters: The Cook/Forster Collection of the Georg-August University of Göttingen (National Museum of Australia 2006: 59) 
The location of these objects in Göttingen reflects the late eighteenthcentury connection between Britain and Germany. In part, this was a scholarly genealogy since two German naturalists Johann Reinhold Forster and his son George accompanied Cook on his second voyage, but it equally mirrored royal genealogical connections between England and Hanover. Johann Friedrich Blumenbach (1752-1840) was the major catalyst in this congregation of objects from the 'South Seas' in the Academic Museum he established in 1773 at the Georg-August University (founded in 1737). A few objects were donated by Johann and George Forster after the second voyage, but the initial nucleus was the result of Blumenbach's close contacts with Joseph Banks and a petition to King George III, then both ruler of Britain and Elector of Hanover, to donate something of 'the surplus of natural curiosities ... collected in large quantities on the recently completed voyages around the world on Your Majesty's command' (cited in Hauser-Schäublin and Krüger 2006c: 21). His appeal succeeded and a 'regal gift' of 349 objects obtained from several London art dealers, and in particular the forced sale of the private collection of George Humphrey, arrived in Göttingen on 15 July 1782. (They were worth 105 pounds sterling, twice the annual income of a Göttingen professor at the time (Hauser-Schäublin and Krüger 2006c: 23).) A few objects had earlier been donated by the Forsters and then, after the death of Johann in 1798, his entire remaining private collection, his 'South Seas estate', was acquired by the Museum in 1799. As Adrienne Kaeppler has consummately shown, Cook voyage artefacts, including those collected by the Forsters are widely dispersed: in the Pitt Rivers Museum and Christ Church in Oxford (see Coote 2004), the British Museum, the Cambridge University Museum of Anthropology and Archaeology, in Scotland, Vienna, Bern, Wörlitz, Florence and Saint Petersburg. But the Göttingen collection is a very significant, wellpreserved and relatively well-provenanced collection. ${ }^{4}$ It has long been a source for study by scholars.

4 The complicated history of the dispersal and congregation of Cook voyage artefacts has been long investigated by Adrienne Kaeppler, and more recently she considered the collection of Joseph Bank's arch rival, Ashton Lever (Kaeppler 2008, 2009a). He amassed the largest collection of Cook voyage artefacts, first in Elkington Hall and then in the Leverian Museum in London. His museum displays stressed the singularity of the objects rather than plotting them in an evolutionary narrative: e.g. the chief mourner's costume from Tahiti was proximate to Oliver Cromwell's dress and a Turkish costume. Like many eighteenth-century collectors, including Johann Reinhold Forster and George Humphrey, Lever was forced to sell his collection to defray large debts. It was offered to the British Museum but Banks campaigned successfully to have them refuse it. It went to auction in 1806 and was dispersed in several 
Johann Friedrich Blumenbach used the collection for both research and teaching, famously arguing that all peoples are 'true humans', mere varieties (Spierlarten) of the same species (Blumenbach 1775) and using artefacts in his lectures on comparative Völkerkunde (ethnology; a habit extended by Heren into the nineteenth century). Both Johann Wolfgang von Goethe and Alexander von Humboldt drew inspiration from the collection. But, after Blumenbach's death, the Museum was dissolved and the Oceanic objects (together with those from other regions) languished in storage for decades. Then in 1935-36, they were recongegrated and displayed in their present location at the Theatreplatz in Göttingen, under the direction of the new Chair of Ethnology, Hans Plischke, whose anthropology was confidently conjugated with colonial history and the less generous view of the 'varieties' of the human race associated with National Socialism. This rather austere building, described by the then Director $^{5}$ as 'unspectacular, rather neglected' (Hauser-Schäublin and Krüger 2006c: 18) is their home to this day, despite strenuous efforts to use the public relations potential of the collection to renovate and extend both museum and teaching facilities. ${ }^{6}$

The collection has been studied by several anthropologists more recently: Adrienne Kaeppler's pioneering work on 'artificial curiosities' and on the Göttingen collection in the international context of Cook voyage artefacts

private collections in Russia and Austria and several British museums. Of 26,000 objects, 1,859 came from the Pacific and 1,784 from the Cook voyages. Most of these were bought for the collection of the AustroHungarian Empire in 1821-26 and displayed in the Museum für Völkerkunde in Vienna from 1928.

5 Brigitta Hauser-Schäublin was director at the time of the exhibitions and the writing and delivery of my 2008 lecture; she has since retired.

6 It was built in the 1930s under the then director Hans Plischke (1890-1972), whose work on anthropology and colonialism is situated, on a board in the foyer, in the context of National Socialism. During her appointment as Professor and Director, Brigitta Hauser-Schäublin put tremendous effort into a plan to restore and expand the building, creating new spaces for the collections and the teaching. These plans were far advanced and approved by the Labor government of the state of Lower Saxony in 2001, but the decision was reversed by the incoming Conservative government. The architectural plans are displayed on the walls of the Institute, but the efforts at rehousing are now directed towards private donations, through the brochure A New House for Gods and Shamans: World Famous Treasures of Göttingen University Endangered. The architectural plans developed for the new building are still displayed in the old building, perhaps in both lament and hope. The travels of the Cook/Forster collection to Honolulu, Canberra and Paris, and subsequently to an exhibition in Bonn which opened in August 2009, James Cook und die Entdeckung der Südsee (and then travelled to Vienna and Bern) were clearly a way of raising the local profile and securing the future condition of the collection. See the book catalogue of the latter exhibition published in German and English in sumptuous illustrated editions (Fleck and Kaeppler 2009). 
(1978a, 1978b, 1979, 1988, 1998, 2006, 2008, 2009a, 2009b); Brigitta Hauser-Schäublin and Gundolf Krüger's edited collection on these 'gifts and treasures from the South Seas' (1998) and cognate publications in recent catalogues (2006a, 2006b, 2006c); and Nicholas Thomas's critical reflections on collecting, the projects of Enlightenment anthropology, and especially Cook, Johann Reinhold and George Forster (1994, 1996, 1997, 2003, cf. J.R. Forster 1996 [1778], G. Forster 2000 [1777]).

In 2006, the objects of the Cook/Forster collection temporarily moved back to Oceania: first to Honolulu and then to Canberra.

\section{To Honolulu}

First, the words of the contemporaneous custodians of this collection, Brigitta Hauser-Schäublin and Gundolf Krüger on the passage of these objects:

After more than 200 years, the world's largest collection of artefacts assembled during the three voyages of James Cook (1768-1771, 17721775, 1776-1979/1780) has travelled back to the Southern Hemisphere where most of the items were made, used and finally traded to crew members of ships of the British Admirality ... Exploration of the Pacific - an endeavour with primarily scientific goals - had unpredictable consequences for many of the peoples 'discovered' in the course of the voyages: illness, suffering and European colonisation. After long, painful decades and even centuries of oppression, growing claims of self-determination across the Pacific in the twentieth century resulted in the realisation of cultural and political autonomy ... When we look at the beautifully preserved artefacts ... we can ponder the changes that have taken place in the world over the past two centuries. The seemingly unchanging character of the artefacts suggests a journey back in time (Brigitta Hauser-Schäublin and Gundolf Krüger 2006a: 15).

As Hauser-Schäublin and Krüger noted, it was two centuries before the objects in the Göttingen collection moved back to the Pacific, in two widely publicised exhibitions in two locales, first from 23 February to 14 May at the Honolulu Academy of Arts (now Honolulu Museum of Art) and then from 1 July to 10 September 2006 at the National Museum of Australia (NMA) in Canberra. As Hauser-Schäublin and Krüger have emphasised (1998, 2006a, 2006b, 2006c), the 'seemingly unchanging character' of the objects is an illusion: they move with the changing 
perspectives of time and place. This was no less true for the movement from Honolulu to Canberra. There were significant affinities between the two exhibitions ${ }^{7}$ but I here focus on the intriguing differences, differences distilled in their divergent titles: in Honolulu, Life in the Pacific of the 1700s; in Canberra, Cook's Pacific Encounters. As the objects moved, the curatorial objects and the frames for their display also shifted. But were the spectators of these objects moved in different ways? And were the relations constructed between these Oceanic objects and living Pacific peoples different in the two sites?

Stephen Little, then director of the Honolulu Academy of Arts, was very clear about their collective curatorial purpose. ${ }^{8}$ In his letter of invitation to conference participants, he enthused: 'These amazing works, made largely before Cook's contact with the indigenous cultures, are extraordinary for their inherent beauty, craftsmanship and unique mana (spiritual power)' (Little 2006a). In a press release he elaborated:

We recognize that the legacy of Cook's voyages in the Pacific included disease and death for many cultures of the Pacific - a fact Cook himself recognized. The purpose of this exhibition however is not to glorify Cook, but on the contrary to celebrate the brilliant cultural and spiritual lives of the indigenous peoples of the Pacific, as they existed prior to the first contact with Westerners. As such the exhibition represents a rare opportunity for cross-cultural understanding that may not come to Hawai' $i$ again for many years. In a world that is still dealing with the aftermath and ongoing realities of colonialism, I hope this exhibition will shed new light on life in the Pacific in the 1700s. The Academy is working closely with members of the Hawaiian, Maori, and Tongan communities,

7 Alongside the Oceanic objects, the Honolulu exhibition included paintings by Sydney Parkinson from the first voyage, William Hodges from the second voyage, and John Webber's images of Hawai' $i$ from the third voyage. The Canberra exhibition included additional objects from Australian collections: Hodges's View from Point Venus, Island of Otaheiti, 1774 (National Library of Australia); the Portrait of Captain James Cook RN, 1782 (National Portrait Gallery, Australia); first editions of voyage accounts held by the National Library of Australia; and various objects attributed to Cook: a station pointer and case, a 'gunner's quadrant', a sextant and an ivory scale rule, held by the State Library of New South Wales (NMA 2006:103-5).

8 I should note that the idea for the exhibition to travel to Hawai $\mathrm{i}$ came from Peter Ruthenberg who is described in the catalogue (Little and Ruthenberg 2006b) as an art historian, collector and designer. Of German descent, he had long lived on the island of Kauai and was instrumental in engaging the curator Gerry Barton, from New Zealand, who had previously worked in Germany. Ruthenberg was appointed Special Advisor on the project, and Stephen Little delegated most decisions about it to him. According to Elfriede Hermann, he routinely desired the 'best' for the exhibition and publications, from the scale and quality of the catalogue to the expertise of the scholars invited (pers. comm., 1 July 2008, Nicolasberg). 
as well as other Pacific Islands cultural specialists, to develop the interpretive and educational programs that will accompany the exhibition (Little, 26 January 2006b: 3). ${ }^{?}$

The exhibition justified the hype. It was stunning. There were several masterpieces: a heva tüpäpa'u, the famous chief mourner's costume from the Society Islands, Tahiti; three taumi (breast ornaments or gorgets) also from the Society Islands; valuable baskets from Tonga and in the privileged centre of the exhibition the grimacing head of ki $i$ akua bulu manu (made of wickerwork: red, yellow and black birds' feathers: dogs' teeth; mother of pearl: and wood), an image or rather an embodiment of Kuka'ilimoku (Kū) the Hawaiian 'war god', which was the focus of Hawaiian attention (Tengan 2016; see Figure 2). An extraordinary range of barkcloth, baskets, ornaments, musical instruments, weapons, and a huge array of fishhooks were displayed. The simplicity of the glass cases lined with pale blue felt evoked the ocean and the objects were brightly lit, amplifying the iridescence of shells, greenstone and feathers. ${ }^{10}$ Because they were grouped not by country but by type, deep Oceanic connections and underlying cultural affinities were highlighted (see Figure 3). But deeper questions about the relation between form and function and the transformations in the manufacture of similar objects across the Pacific were not developed (Drake 2007: 343). Moreover, it meant that visitors, especially Pacific people, who sought to engage with the cultural heritage of particular places or specific countries, for example Hawai'i or Tonga, were unable to do so (see Andrade 2007 and Drake 2007). Labels were minimal-with name, origin and inventory number (e.g. 'club patu meremere, wood, New Zealand, Inv. Oz 275')—and devoid of any cultural contextual information which would illuminate use or meaning.

9 In elaboration, Little advanced four major reasons for the exhibition. 'First the museum has always represented the indigenous cultures of the Pacific in its collections and has supported these cultures (particularly native Hawaiian culture), ever since the museum opened in 1927' (2006a: 5), this was central to its primary mission of education through works of art. 'Second, these artifacts were for the most part created before Cook encountered these indigenous peoples. Their condition is largely pristine' (2006a: 5 emphasis in the original. He stressed that experiencing the 'visual and spiritual power' of the original works 'could not be duplicated in a book or electronic image'. 'Third, this exhibition demonstrates the close connection between ancient cultures in the Pacific-cultures that were often separated by great distances across the ocean' (2006a: 5). This was highlighted by the genre of display: works of similar function and manufacture were displayed together. 'Finally, the exhibition poses the question: what is the role and relevance of the indigenous cultures of the Pacific today? The works in the exhibition, both mundane and sacred, are windows into the past, present and future' (2006a: 6).

10 Karen Kosasa (2007) also commented positively on the display, which she thought enabled that close aesthetic attention, which Svetlana Alpers has described as 'the museum effect' (1991). 
This 'text-free' curatorial strategy was widely applauded by some of the 65,000 people who visited and by some reviewers in the Honolulu daily press, for letting 'objects tell Pacific peoples' stories' (Carvalho 2006). Others suggested that the lack of such interpretive material left spectators frustrated and craving more information and that the presentation of objects as 'art' without indigenous perspectives was, in the view of Tongan cultural practitioner and Bishop Museum curator, Maile Drake like seeing a 'body without a soul' (Drake 2007: 343). Ivy Hali'imaile Andrade, echoed this critique, finding the presentation of the objects as artefacts or art as 'cold': 'As a Hawaiian I am linked genealogically to the pieces from Hawai' $i$ lying behind the glass cases; they are my ancestors. The lack of interpretive materials in the galleries relegated the works to mere historic "objects" (Andrade 2007: 342).

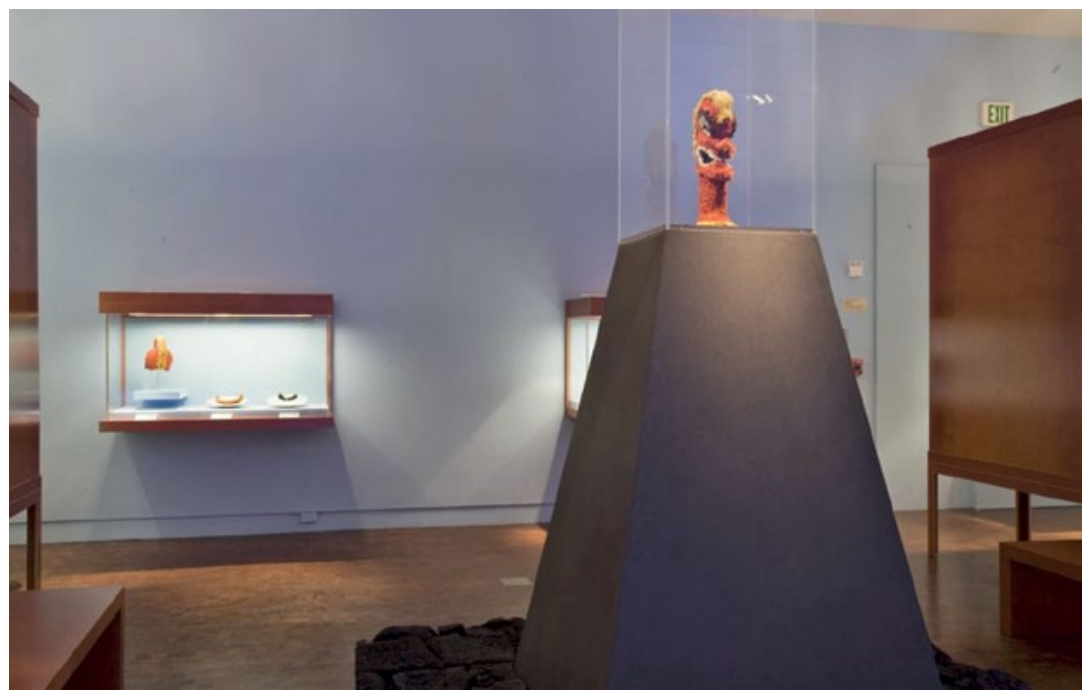

Figure 2. A Hawaiian ki' $i$ akua hulu manu in a glass case on a pedestal in Life in the Pacific of the 1700s: The Cook/Forster Collection of the Georg-August University of Göttingen, 23 February-14 May 2006, Honolulu Academy of Arts

Source. Photograph by Shuzo Uemoto, reproduced courtesy of the Honolulu Museum of Art 


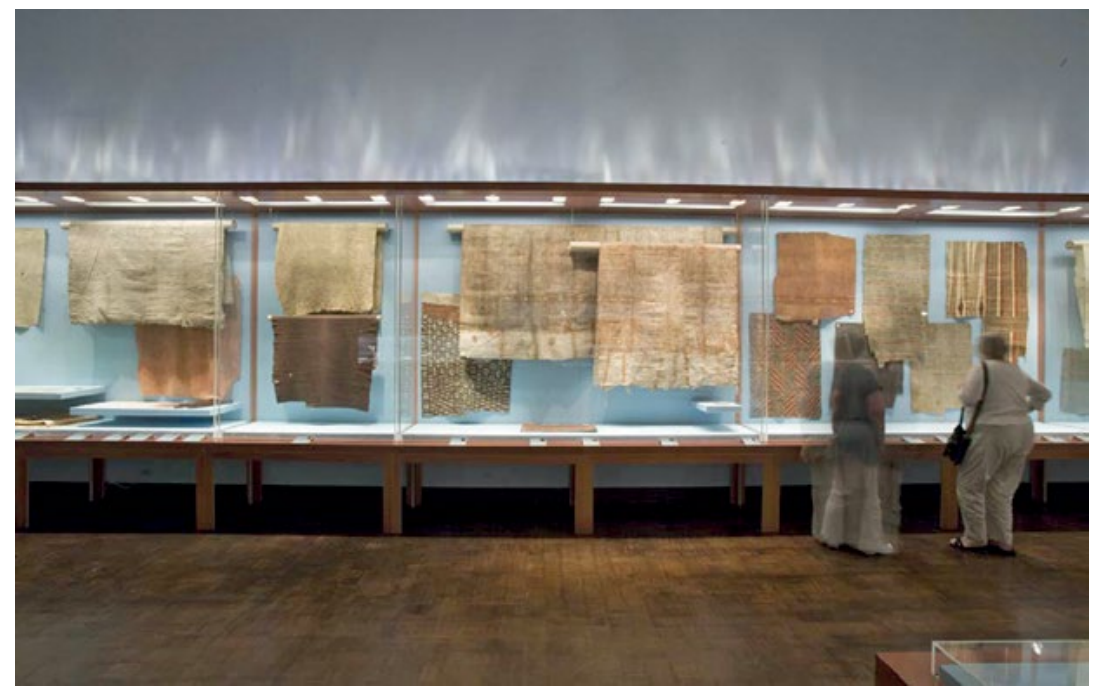

Figure 3. Barkcloth from many different Pacific places on display in Life in the Pacific of the 1700s: The Cook/Forster Collection of the GeorgAugust University of Göttingen, 23 February-14 May 2006, Honolulu Academy of Arts

Source. Photograph by Shuzo Uemoto, reproduced courtesy of the Honolulu Museum of Art

Still, comments in the visitors' book suggested that many indigenous Hawaiians were moved by the Hawaiian objects in the exhibition, particularly by the presence of Kü, since offerings were left in front of the high pedestal where he was elevated. ${ }^{11}$ But some thought, having come home, Kū should remain. Jonathan Osorio, then director of the Kamakakūokalani Center for Hawaiian Studies at the University of Hawai' $i$ at Mānoa (UHM) observed that since the objects were not stolen their ownership belonged with the Göttingen Museum, but that it would be a 'wonderful gesture' if the Hawaiian objects could be housed permanently in Hawai' $i$. The decision to make such a donation, he said, 'is something left up to the conscience of the people in the museum in Germany' (Pang 2006: 2). One Hawaiian visitor to the museum even asked 'When can we rebury them'? (Ulrich Menter, pers. comm., 30 June 2008, Göttingen). Moreover, several Hawaiians

11 Ivy Hali'imaile Andrade's critique of its display is revealing. 'I found the altar-like setting perplexing and there was no explanation for it. It seemed overly dramatic, and I feel encouraged people to leave ho'okupu (offerings), not understanding how this particular Kü (ancestral deity associated with politics and war) may have functioned as a private god for designated followers rather than a public god for all to worship' (2007: 342). 
and other Pacific Islanders, including several scholars at the University of Hawai' $i$ at Mānoa complained that the absence of indigenous voices and perspectives which would have enabled deeper processes of crosscultural translation (Andrade 2007: 341-42; Drake 2007: 343; Kosasa 2007: 344), also suppressed the vaunted link between past and present. ${ }^{12}$ Isolating the pristine beautiful objects and letting them speak seemed in danger of silencing contemporary indigenous interpretations and perhaps the political tensions and impurities of the present.

Both the title of the exhibition Hele Mai: Life in the Pacific of the 1700s and the form of display stressed the ancient, pristine, pre-contact character of the objects. Curators emphasised that there were no introduced fibres or dyes, no beads, no glass, no metal. Though often exchanged for European things, these Oceanic objects showed no 'traces of such imported material' (Hauser-Schäublin and Krüger 2006c: 16). Analysis of the context of European voyaging and of collecting in the late $1700 \mathrm{~s}$ was thus rather muted in the exhibition, though not in the exhibition guide and the huge three volume catalogue which appeared later that year (Little and Ruthenberg 2006a, 2006b). Some well-known voyage portraits and landscapes by William Hodges, Sydney Parkinson's drawings of Pacific plants and John Webber's images of Hawai'i were mounted proximate to the main exhibition, but these seemed like an annex rather than integral to the show.

Little's invitation stressed the comprehensive educational program that accompanied the exhibition: a scholarly conference, lectures, films and cultural performances. He highlighted the indigenous presence in the opening events of Voyage to the South Pacific in ARTafter DARK on 24 February 2006. There were welcoming performances of hula by La'akea Suganuma and his daughters, Kawena, Pele and Kuhilani, great granddaughters of Mary Kawena Puku'i who introduced public hula performances to the Honolulu Academy of Arts in the late 1930s and 1940s (see Figure 4). Hawaiian chants were sung, a Tongan tapu lifted, and Māori, Tahitian and Tongan dancers performed. The Cook/Forster exhibition was accompanied by a photographic exhibition on Life in the Pacific of the 21st Century, which aspired to make 'connections between

12 Ulrich Menter stressed the varying Hawaiian responses as recorded in the exhibition's visitor books. His colleagues at the UHM Center for Hawaiian Studies were in general critical, probably because of the interaction with the simultaneous Kawaihae dispute (personal communication, 30 June 2008, Göttingen). 
past and present' and drew school students, parents, küpuna (elders), community leaders and scholars into discussions about the eighteenthcentury objects. The Academy's Education Department provided digital cameras, with which participants shot nearly 7,000 images, of which 80 were selected to hang in the central courtyard of the Academy and in the foyer of the Outrigger Waikiki at Diamond Head. Still, despite these efforts to engage local people in the educational and interpretive programs, the broader involvement of Pacific Island curators and communities in planning and decisions about the exhibition, conference and educational programs was seen by many as insufficient (Andrade 2007: 142).

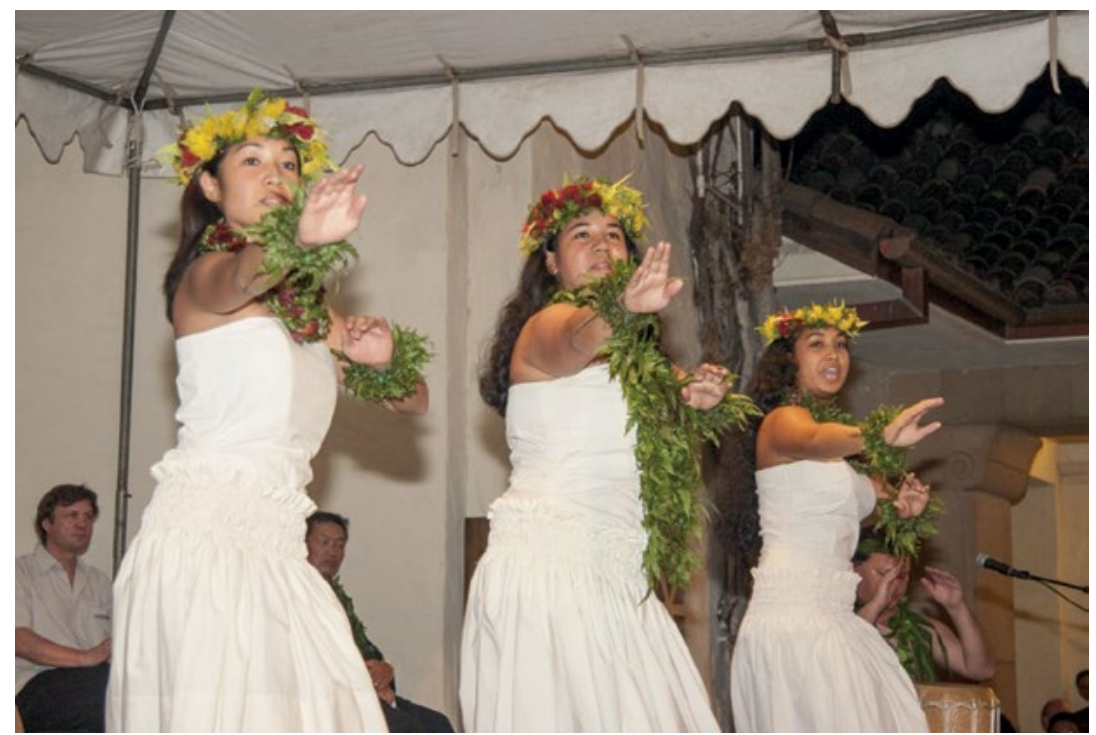

Figure 4. Kawena, Pele, and Kuhilani, daughters of La'akea Suganuma, perform hula as part of the opening ceremonies for Life in the Pacific of the 1700s, Honolulu Academy of Arts, 24 February 2006

Source. Photograph by Shuzo Uemoto, reproduced courtesy of the Honolulu Museum of Art

Moreover, the efforts to engage local Hawaiian and Pacific communities were vitiated by two major problems surrounding the exhibition's opening and the accompanying scholarly conference (see Kosasa 2007: 344). La'akea Suganuma, then president of the Royal Hawaiian Academy of Traditional Arts, who was chosen to enact the sacred protocols, the blessing in Göttingen on 23 January 2006, as part of the homecoming for the Hawaiian treasures and to perform the welcoming hula with his three daughters on the opening night, had been involved in a bitter 
dispute with other Hawaiians about the reburial of human remains and ancient funerary objects on loan from the Bishop Museum. The details of this controversy, the Kawaihae Caves case, are complex and difficult to distill (but see Johnson 2007 and note 13). Suganuma and Abigail Kawananakoa had brought a lawsuit against another group of Hawaiians, Hui Mālama i Na Kupuna o Hawai'i Nei and the Bishop Museum whom they alleged had violated a repatriation process authorised through NAGPRA (the Native American Graves Protection and Repatriation Act, a federal law of 1990). In 2001 Hui Mālama reburied human remains (bones or iwi) and then proceeded to rebury 83 objects which had been loaned to them by then Museum director, Donald Duckworth. ${ }^{13}$ The law

13 This repatriation dispute is variously referred to as the Kawaihae Caves or 'Forbes Cave' dispute in the Honolulu press (see Office of Hawaiian Affairs Newsletter 2006; and Wong 2006a, 2006b, 2006c). It was enabled by the passing of NAGPRA (the Native American Graves Protection and Repatriation Act) by the federal legislature in 1990. Hui Mālama were one of four original claimants, registered as 'Native Hawaiian organizations' or NHO, who made a claim for repatriation of both human remains (bones, iwi) and burial objects taken from Kawaihae Caves in 1905. An amateur archaeologist, David Forbes, had removed both bones and 83 artefacts and sold them to the Bishop Museum. Later 'explorations' of the same 'Forbes Cave' and adjacent caves resulted in the removal of more bones and objects to the Bishop Museum and Volcanoes National Park during the 1930s. Repatriation processes were commenced and in the late 1990s human remains were given and then in February 2000, 83 'priceless objects' were loaned to members of Hui Mālama. Soon after they sealed both objects and remains in the caves, with rebar and concrete at the mouth of the lava tube. At this point the four claimants all agreed to bury the bones and the objects which had been loaned by Donald Duckworth, then director of the Museum because repatriation was not technically completed and a loan was the most expeditious form of transfer while the legal process was ongoing. But subsequently other claimants came forward to suggest that the repatriation was flawed since not all NHO were consulted. Amongst these were the Royal Hawaiian Academy of Traditional Arts, led by its president La'akea Suganuma (a grandson of Mary Kawena Puku'i), and much later in 2005, Na Le'i Ali'i Kawananakoa, led by Abigail Kawananakoa, with links to Prince Kūhiō. Of the 13 claimants by 2001, some were for and others against the reburial of the objects. In August 2001 a 'Document of Truth' was signed by all, including Suganuma that they would 'agree to disagree'. But, shortly after, Suganuma filed a complaint with the NAGPRA review committee who ruled in his favour. Then in 2004 a lawsuit was filed by both the Royal Hawaiian Academy of Traditional Arts and $\mathrm{Na} L e{ }^{\prime} \mathrm{i}$ Alíi Kawananakoa against both Hui Mālama and the Bishop Museum. Eventually, District Court Judge David Ezra ordered Hui Mālama to retrieve the objects or disclose their exact location. Hui Mālama responded with the GPS co-ordinates and an inventory but refused to divulge more and Edward Halealoha Ayau, as head of the board, was imprisoned for contempt of court for three weeks in a federal detention centre between December 2005 and January 2006. Ayau was released (but still subject to home detention and a monitoring device, Wong 2006b). Hawaiian mediation, ho'oponopono, was tried and failed and eventually Judge Ezra had the objects removed about AugustSeptember 2006 and returned to the Bishop Museum.

As Greg Johnson observes $(2007,2009)$ this is a poignant and telling case of making meaning in the present through laying claim to the dead and of how culture is animated by contestation. On the one hand, Hui Mālama and the other claimants who supported reburial of the objects, insisted that they were moepu or 'buried with the dead', because of the disposition of the objects in front of the bones (Ka Wai Ola September 2005: 7). Moepu, they argued, were invested with the mana kupuna (ancestral spiritual power) of the deities, and were there to guard the dead, in this case high-ranking ali $i$ (chiefs) from this area of the Big Island of Hawai i. Those who opposed their reburial suggested they were not funerary objects, that moepu was only a word in the context of ho omoepu (to place with the dead, 
suit resulted in the prosecution of Hui Mālama for contempt of court in failing to return the objects or divulge their exact location, and the imprisonment of its leader Edward Halealoha Ayau for several weeks in December 2005-January 2006. So, just as the exhibition was opening at the Honolulu Academy of Arts, the protagonists were engaged in sensitive negotiations using Hawaiian mediation techniques. These failed and subsequently the objects were recovered and returned to the Bishop Museum around August 2006.

\section{This dispute which Greg Johnson has depicted as 'Hawaiian to its very marrow' (2009: 6) engaged profound cultural questions about the rival claims of the living to look after the dead. As Johnson shows, there is an intimate link between this dispute and an earlier controversy about the 1994 theft from the Bishop Museum of 'royal caskets' or $k \bar{a}$ 'ai, which had been deposited on loan by Kawananakoa's ancestor, Prince Kūhiō. These}

lit. to put to sleep with). La'akea Suganuma wrote, 'An object placed is still an object'. He claimed they were rather precious objects which had been placed in this cave for safe-keeping at a time of conversion to Christianity with the end of ai kapu (taboos) restrictions in 1816 and the destruction or desecration of many sacred objects. He further suggested that it was ancestral intention that once the kapu was lifted that the cave be 'found' and the objects preserved to be a living lesson on Hawaiian life for descendants, that the return of the objects to the museum was thus the will of the ancestors.

This disagreement dates back to the early twentieth century, as attested by documents in the museum. In 1906 its then director Brigham said there was no evidence to support the theory they were hidden from being destroyed and that the objects were 'personal keepsakes' and 'household deities of the dead'. But later documents, relying on oral traditions, claim one of the figures was buried 'at the time of the destruction of the idols'. Both sides in the current dispute lay claim to acting in the best interests of the küpuna (ancestors/elders) and Hawaiian culture. But in these contesting claims to authority there are also genealogical differences. Both Suganuma and Abigail Kawananakoa claimed aristocratic pedigree: he is descended from Mary Kawena Puku' $i$, while she is a direct descendant of Prince Kūhiō. As Johnson observes 'In contrast to her purportedly royal status, she has declared that others, and especially members of Hui Mālama are maka'ainana-commoners-who have no right to speak for the dead and their things' (Johnson 2009: 23), and especially not for dead ali 'i, it seems. Johnson analyses the crucial links between this dispute and a former controversy over the theft of $k \tilde{a}^{\prime} a i$, royal caskets, from the Bishop Museum in 1994. These caskets and their uncertain remains (perhaps of two kings of the fifteenth and sixteenth centuries) had been moved many times before in a series of struggles between Hawaiians for control over their mana (spiritual power), including one between Queen Lilíuokalani and Prince Kühiō. After her death he placed them in the Bishop Museum on a loan. Abigail Kawananakoa makes an explicit link between the Kawaihae Caves case and the theft of the $k \dot{a} a \dot{a}$, as a way of acting in defence of her ancestors. But the link is broader as Johnson suggests, since both pertain to the same area of the Big Island between the Waipi'o Valley in the north and Kealakekua Bay in the south, homeland of King Kamehameha, who sacrificed at Pu'a Kohala to accomplish his goal of uniting the islands. The Kawaihae Caves are just above. The struggle between the ancient Hawaiian religion and Christianity was most intense in this region. Struggles about both the $k \bar{a} a i$ and Kawaihae objects are 'about reconstituting the power of the past in the present' (Johnson 2009: 24). These repatriation disputes are neither 'merely political', nor a sign of the 'decayed state of Hawaiian culture' but a sign that through invoking cultural and religious arguments in contests of responsibility towards and authority over the dead, 'the dispute is Hawaiian to its very marrow' (Johnson 2009: 6). As with the Jesus of Christianity there is no pure origin story, no unifying harmonious culture, but rival traditions which in their very contestation, animate 'culture'. 
$k \bar{a}$ 'ai had been 'moving objects' for over a century; they were constantly relocated in struggles over the claims of rival royal pasts in the present, for example, between Prince Kūhiō and Queen Lilíuokalani. Both these disputes were grounded in the turbulent political landscape of the Big Island, from Kealakekua Bay, where Cook was killed, to Waipi'o Valley, the homeland of King Kamehameha who unified the islands. Some Hawaiians and other locals thought the intimate involvement of both Suganuma and Kawananakoa in the opening ceremonies on 24 February 2006 was insensitive at best and provocative at worst and chose to boycott both the opening and the exhibition. Yet, in an interview in the Honolulu Advertiser on 4 February, Little declared that he did not anticipate criticism of the exhibition and stressed that the exhibited items were not stolen but given to Cook and should not be confused with or associated with the high-profile court case [i.e. the Kawaihae Caves case]' (Pang 2006: 2). But although the objects might have been so differentiated, the claims of living subjects were connected and associations were made. This rather compromised the 'rare opportunity for cross-cultural understanding' that Stephen Little had envisaged..$^{14}$

Second, despite the best efforts of the conference organisers and especially of Elfriede Hermann who issued many invitations, ${ }^{15}$ Pacific Islander scholars were sparsely represented, as speakers, chairs, or participants at the conference Changing Contexts - Shifting Meanings: Transformations of Cultural Traditions in Oceania (Hermann 2011). Scholars from Europe, North America, Australia and New Zealand predominated. After Jacob Simmet from Papua New Guinea and Ropate Qalo from Fiji belatedly withdrew, the sole Pacific Islander speaker was Amy Ku'uleialoha Stillman from Michigan who spoke consummately, as always, on modern hula as a

14 Elfriede Hermann insisted that Little was keen to have active engagement by many Hawaiians and solicited their communication with the image of Kū during the exhibition: some spoke to Kū, others surrounded him with leaves in blessing (Elfriede Hermann, pers. comm., 1 July 2008, Nicolasberg). Some of the difficulties which emerged may have been ameliorated if the Academy had earlier sought advice and assistance from colleagues at the University of Hawai' $i$ at Mānoa who were strikingly few as speakers at the conference. I am uncertain how far the Kawaihae Caves dispute led to a call for a boycott of both exhibition and conference. Little tried to downplay the connection in interviews with the press. 'The Germans are legally the owners of the Cook artifacts ... Everything in the show is either a gift to Cook or traded with Cook for something he had. So there's nothing in the show that was stolen; there's nothing in the show that was a burial object. These are all things that were above ground' (Pang 2006: 2).

15 Elfriede Hermann had invited Ralph Regenvanu, Lilikalā Kaméeleihiwa, J. Kēhaulani Kauanui, Epeli Hau'ofa, Jacob Simmet and Ropate Qalo amongst a list of about 12 Islander scholars. All had to decline because of prior commitments. The invitations were issued rather late by the Honolulu Academy of Arts so this might also have been a factor. 
crucible of Hawaiian tradition. The unfortunate absence of Pacific Islander scholars finally surfaced in the closing plenary when the discussants, Aletta Biersack and Peter Hempenstall suggested that the presence of more Pacific Islanders would have enriched our debates. A number of us echoed these sentiments and Amy Ku'uleialoha Stillman stood up and passionately lamented her sense of discomfort and isolation. ${ }^{16}$ In the midst of this fraught plenary discussion, Stephen Little invited us to listen to the eloquent ancestors, those loquacious objects, speaking upstairs in the galleries. This appeal to a mythical past of harmony and wisdom to ameliorate the present tensions seemed to parallel how a curatorial stress on the pristine had rendered contemporary cultural politics unseemly (see Johnson 2009).

\section{To Canberra: Cook as hook}

Life in the Pacific in the 1700s in Honolulu transmuted into Cook's Pacific Encounters in Canberra six weeks later. Cook's Pacific Encounters at the NMA in Canberra was widely promoted as the only chance in the Southern Hemisphere' to see these extraordinary objects Cook had collected. Cook was the hook to lure visitors to this show. Expensively advertised on television and in the print media, generously sponsored by Singapore Airlines, Prime Television, Art Exhibitions Australia, and the Australian government's Art Indemnity Australia, it proved rather popular with visitors.

Although the same objects were displayed in rather similar ensembles to Honolulu, some in more alluring ways with subdued lighting (such as the cases of fishhooks and jewellery, see Figure 5), the show in Canberra emphasised far more the European context of collecting. Instead of European maps, engravings and paintings being located as an annex to the main display of Oceanic objects, they were rather situated as the direct introit, as a narrative precursor to them. On first entering the gallery the spectator was confronted with two giant maps. One showed the 'probable migration routes' of Pacific peoples (a justified tentativeness since my

16 Amy Ku'uleialoha Stillman subsequently wrote a reflective essay 'On academic voyages of encounter' (n.d.) comparing her experience of this conference with that of Culture Moves, held at Te Papa Tongarewa in November 2005. She shared this essay with me but it remains unpublished. I thank her for permission to mention it here. 
colleague, eminent ANU Pacific archaeologist Matthew Spriggs, declared it so out of date he felt his entire career had been in vain). The other showed Cook's rather more certain tracks on his three voyages.

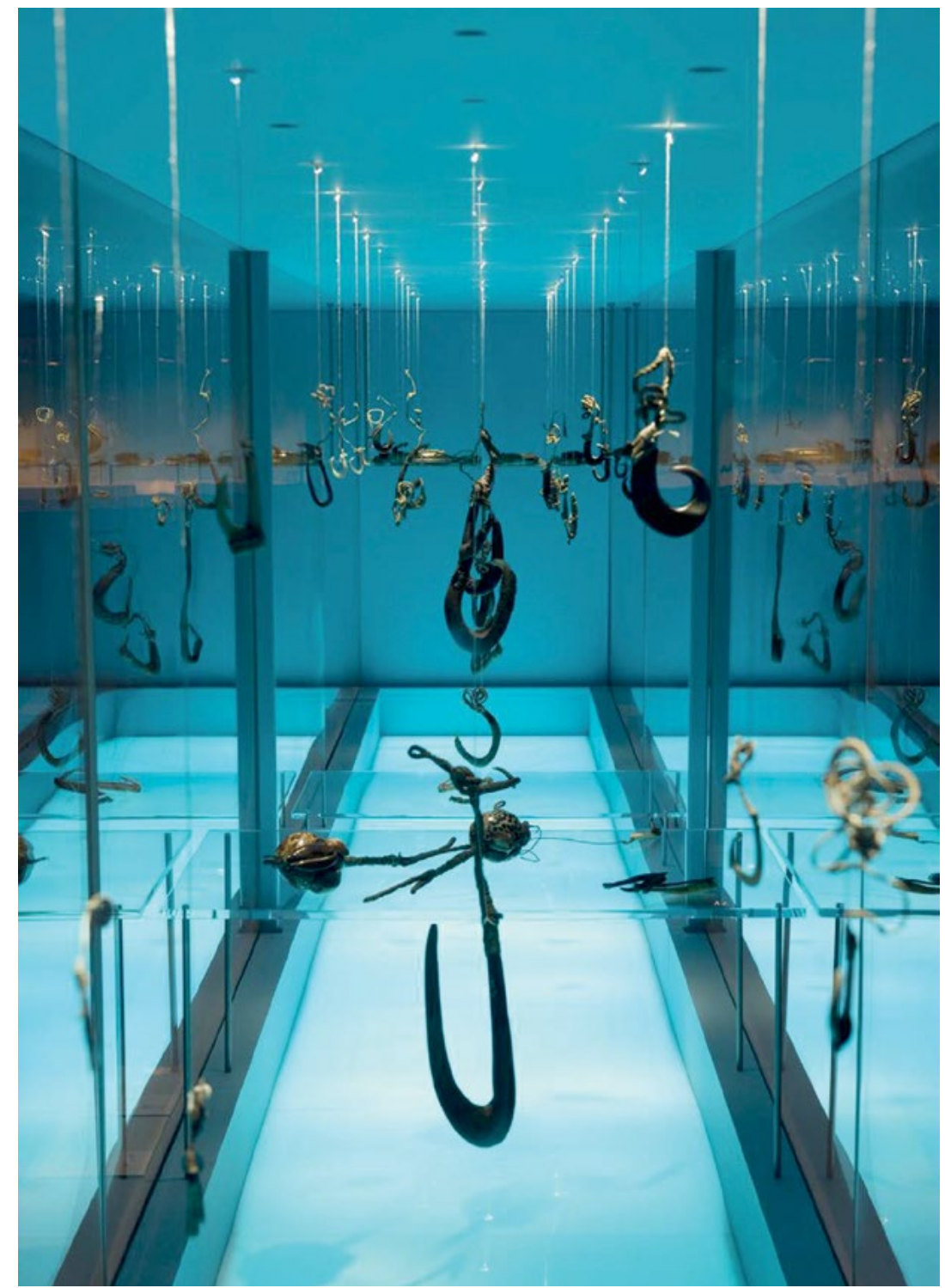

Figure 5. Fishhooks from many Pacific Islands on display in a glass case in Cook's Pacific Encounters, National Museum of Australia, 2006

Source. Photograph by George Serras, reproduced courtesy of the National Museum of Australia 
Besides the vitrines encasing the objects were banners with quotes from the voyage texts, highlighting the exchange processes in which objects were traded with or 'gifted' to the Europeans. The central focus was thus on exchange and the privileged figure was Cook and his Pacific encounters (rather than the German naturalists Johann Reinhold and his son George Forster who are, in Australia, far more obscure figures, known mainly to scholars). Contemporary German-Australian cultural exchange was celebrated at the opening of the exhibition, at which the German ambassador and then director of the Institute for Ethnology at the Georg-August University of Göttingen, Brigitta Hauser-Schäublin, were present. In the accompanying catalogue, the then director of the NMA, Craddock Morton, readily acknowledged that in the Australian context it was irresistible and justifiable to highlight the Cook connection. Perhaps the curators in Honolulu had desired rather to downplay that connection, given Cook's rather different 'posthumous reputation' there (see Smith 1992). ${ }^{17}$

I am not suggesting that Cook's Pacific Encounters was innocently hagiographic. Like Little, Morton acknowledged that Cook's Pacific encounters were both 'benign and hostile' (Morton 2006: xi) but he came to the conclusion, echoing Sahlins $(1982,1985,1989,1995)$ and Salmond (2003), that Cook was revered by Pacific people too, and that the man killed in Hawai' $i$ was 'certainly James Cook, but also Tute, Kuki and Orono. A god as well as a man' (Morton 2006: xiii). Whether Cook was perceived as a manifestation of the god Lono by indigenous Hawaiians has of course been the subject of passionate debate between Marshall Sahlins and Gananath Obeyesekere (Obeyesekere 1992; Sahlins 1995). Although Sahlins likely won the intellectual argument about the eighteenth century, Cook's deification is clearly not perpetuated by most twenty-first century Hawaiians; indeed many Hawaiian nationalists rather gleefully celebrate the fact that Hawaiians killed him. Still, Morton ultimately adjudged Cook a heroic discoverer: 'a man of the Enlightenment, bringing the new world to the old' (Morton 2006: xiv). The frame for the Canberra exhibition was thus, far more than in Honolulu, European discoveries: how the collection of objects was as crucial as the recorded observations of peoples and places in text and images, the meticulous collection of flora and fauna, and the attempts, especially by the Forsters on the second

17 As Chris Ballard (2006) has suggested, Cook is still 'fissile material' in Hawai' $i$. 
voyage, to record the languages of the peoples of the Pacific, with the help of interpreters like Tupaia on the first voyage and Omai on the second (see Jolly 2011b).

The NMA exhibition texts and especially the catalogue constantly reiterated that the collection of objects were not acts of imperial appropriation but were for the most part traded or 'gifted' to the strangers. In a catalogue essay, Jenny Newell, then a curator at the British Museum, stressed: 'The passion to acquire exotic objects was mutual' (Newell 2006: 45). Islanders were collecting, not just European things but highly valued Oceanic objects, especially fine white tapa from Tahiti and red feathers from Tonga, which were enthusiastically traded between different islands of the Pacific through the conduit of the voyages. Following Greg Dening and Nicholas Thomas, Newell highlighted how European artefactspainted portraits, bed sheets, and brass casts-became powerful Oceanic objects, enhancing local power and status. Islanders, she claimed, retained the 'upper hand' in such exchanges (in implicit contradistinction to the imperial trophies of later missionaries, travellers and other collectors. See Hooper 2006: 24-27).

Thus, there was an overwhelming focus on mutual exchange in the Canberra exhibition, and, like much writing on Cook, it tended to mist over the violence which was, as George Forster stressed at the time, an inherent part, and not just an unfortunate corollary, of these acts of 'discovery' (see Jolly 1992, 2007b, 2009a, 2009b, 2009c; Jolly with Tcherkézoff 2009). Such violence was often mutual too, but although the reciprocal allure of objects may have been roughly equal or even balanced towards Islanders because of the Europeans' vulnerability in needing fresh food, water and wood, it is hard to claim such parity for weapons of war. Bows and arrows, spears, sling stones and clubs were usually no match for iron weapons, muskets and cannons. In a poignant irony, although Cook was downed with Hawaiian clubs he was finished off with an iron dagger which had been traded for Hawaiian artefacts (see Hauser-Schäublin and Krüger 2006c). Yet, as Bernard Smith (1992: 232-40) long ago observed, in the creation of Cook's image in the European visions of the late eighteenth century and since, there has been a tendency to portray him primarily as a peacemaker. Unlike the more multivalent representation in Cook's Sites (by Mark Adams and Nicholas Thomas), remounted at the National Library of Australia earlier in 2006, which acknowledged Cook's 'dark side' (see Jolly 2007b), Cook was represented at the National Museum of Australia in a light as gleaming as the wintry atmosphere of Canberra outside. 
Curators were perhaps in part responding to pressure coming from the then prime minister John Howard to tell a more positive story of the 'discovery' of Australia and white settlement and to eschew a 'black arm-band history' of colonialism. ${ }^{18}$ Craddock Morton acknowledged the popular lure of Cook for visitors, a national icon of British settler colonial history (see Bolton 2006, 2009). Although the lure of that hook has sometimes been overestimated, this exhibition drew around 26,700 visitors. ${ }^{19}$ There were more critical views of Cook offered at an associated symposium, Discovering Cook's Collections, but these were, for the most part, sequestered there.

As in Honolulu, there was a lone Pacific scholar and curator who spoke at that symposium, Paul Tapsell from the Auckland Museum, along with the Indigenous Australian scholar Doreen Mellor from the National Library of Australia. Pacific curators and scholars from museums in the islands from which the objects originated-Hawai $i$, Tahiti, the Marquesas, Rapanui, Tonga, New Caledonia and Vanuatu-were not invited, and the main commentary thus came from experts from Australia, North America and Britain: the late Greg Dening, Paul Turnbull, Nigel Erskine, Adrienne Kaeppler and Lissant Bolton. Questions about the relationship between Cook's voyages, colonial power and knowledge were addressed, especially in presentations by the late Greg Dening (2009), Paul Tapsell (2009) and Doreen Mellor (2009).

Paul Tapsell spoke of how academic and museological practice still fixates on the figure of Cook. He rather celebrated the role of the Polynesian priest and navigator Tupaia, who remains 'near invisible' in 'official voyage writings' and Eurocentric history, despite his pivotal contribution to Cook's first voyage (2009: 103). He was more than a 'convenient translator who died en route while hitching a ride to England' (2009: 105); without him 'Cook's first footsteps on New Zealand's shores may have been his last' (2009: 103, 105, 93). Tupaia directly facilitated the European exploration

18 This phrase, coined by one of then prime minister John Howard's speechwriters, refers to the dark, funereal laments about colonialism and especially to white settler guilt about extreme violence enacted on Indigenous Australians. The decade or more of Howard's government was marked by passionate scholarly and public debates about the extent of this violence, debates which became known as the 'history wars' (see Macintyre and Clark 2004).

19 Susan Tonkin, then assistant manager of NMA Audience Development \& Public Programs, reported that 'Cook's Pacific Encounters attracted a total of 26,700 visitors during its July to September 2006 season at the National Museum' (pers. comm. by email, 6 November 2009). Bolton (2009) reflected on how Cook's fame can be seen as a kind of celebrity status which attracts visitors to museum exhibitions. 
of the Pacific, through his extensive navigational knowledge, the graphic arts he learnt and in the collecting of Māori taonga (treasured objects), likely given to him as a sign of genealogical connection and trust. Though he died in Batavia, Tupaia's wisdom and assistance ensured that Cook and his compatriots arrived safely home with 'their precious cargo of scientific evidence' (2009: 92). As Tapsell notes, the taonga collected on Cook's first voyage, though likely prestations to Tupaia, have 'remained stratospherically detached' from the new museum practices which have allowed such objects to become 'rehumanised and approachable in a way that enables the customary system of kin-belonging to be positively expressed' (2009: 92). Yet 'like an uncharted rock just below the surface, his [Tupaia's] unrecognised influence continues to ripple and shape our maps, history books and museums' (2009: 107). And in Aotearoa New Zealand Tupaia is still known and cherished by contemporary Māori, seen as their own ancestor, and remembered through those many boys who are named after him. ${ }^{20}$

Doreen Mellor, who comes from the Atherton Tablelands of North Queensland, honoured the 'custodians of this land for millennia before James Cook appeared on the horizon in 1770' (2006) and addressed the 'life-changing consequences for Australian Indigenous peoples of James Cook's first Pacific journey and subsequent European settlement' (2009: 113). While acknowledging the achievements of Cook's first voyage in the Endeavour and Cook's status as a 'powerful symbol of the age of Enlightenment' (2009: 113) Mellor saw the science of exploration as perforce connected to the building of empire. Cook had only fleeting connections with Indigenous Australians on that voyage. The Eora people of Botany Bay refused his beads and nails. Said Cook, 'all they seem'd to want was for us to be gone' (Mellor 2009: 115; see also Nugent 2009). Later in North Queensland, after the Endeavour was holed by the coral

20 Tapsell noted that Māori today remember Tupaia as Tupaea (lit tu: stand, paea: cast ashore; 2009:109). In the language of his homeland Raiatea, it rather means 'beaten', in reference to a military defeat. Māori ancestors recognised him as a man of high rank, emanating from a sacred marae (a communal and sacred meeting ground) in the eastern Pacific who exercised great authority (even over the strangers) and spoke the tapu dialect of the priestly elite. He thinks it highly likely that the treasured dog-skin cloaks (kahi kuri) and greenstone (pounamu) in the collections from Cook's first voyage were prestations to Tupaia (2009: 102-104). Tupaia is now acknowledged as the creator of several watercolours previously attributed to Joseph Banks and has long been recognised as the author of Tupaia's chart. But, as Tapsell argued, after Di Piazza and Pearthree (2007), the original from which several copies were made was not a conventional European map plotted on the co-ordinates of longitude and latitude but a graphic expression of traditional Oceanic wayfinding frames of reference (2009: 95). See Jolly 2011b for a fuller discussion. 
reef at Cape Tribulation and repairs were in process, Cook and his crew encountered the peoples of Gangarr (now Cooktown) and more friendly relations ensued. But when the British refused to share the spoils of their abundant catch of turtles, local people were angered and lit a grass fire around the ship's camp.

Mellor juxtaposed two treasured objects in the collection of the National Library of Australia (NLA), Cook's Endeavour journal with the papers of Eddi Mabo a 'record of his long and ultimately successful endeavour to reclaim as native title the land annexed by Cook' (2009: 116). She stressed how the colonial appropriation of Indigenous land and the dissemination of a racist evolutionary ideology separated and divided white and Indigenous Australians. Such separations culminated in the forcible separation of Aboriginal and Torres Strait Islander children from their families in the period from 1918 to 1970 - the story of the Stolen Generations'-which Mellor suggests can be best accessed through the poignant stories told in the audiotape collection of the NLA. The bicentenary of the arrival of the First Fleet in 1988 was thus more an occasion for Indigenous mourning than celebration. But, concluding with the famous Indigenous motto from that year-'White Australia has a Black History'-she suggests that this signifies not just anger and resistance but the need for mutual understanding and the recognition of the prior presence of Indigenous Australians (2009: 125).

There was thus a powerful and poignant dialogue between the situation of Māori and Indigenous Australians in these two proximate settler colonies. But alas, perhaps because of time and funding constraints, there was no broader conversation with curators and scholars from the broader region of Oceania as represented in the objects of the exhibition or in the diversity of peoples from Oceania who are migrants to Australia.

A later weekend of community activities included a dialogue between Ralph Regenvanu from the Vanuatu Cultural Centre and Lissant Bolton from the British Museum. But, compared to Honolulu, not much was done to engage local Pacific communities nor to foster a dialogue about the relation between these ancient objects and the living culture of Pacific peoples in Australia. Māori and Tongan dance groups were invited as part of the lavish opening night performances, but Islanders were not included in projects or conversations around the objects, as was attempted with Pacific communities in Hawai $i$. There was thus little to link the objects 
with the 'living cultures' of Pacific migrants in Australia. In September 2006, most objects from the exhibition returned to Göttingen, while a few moved on to Paris, to be exhibited at the Musée du Quai Branly in late 2006.

\section{A difficult passage}

How then might we see the passage of these moving objects of the Cook/ Forster collection to Honolulu and Canberra in relation to the three questions I posed at the outset?

First, did these exhibitions evince more open and dialogical relations of knowing, more interactive collaborations and more egalitarian curatorial postures, which proponents of the 'new' museum avow? In Honolulu, Stephen Little spoke of celebrating 'the brilliant cultural and spiritual lives of the indigenous peoples of the Pacific, as they existed prior to the first contact with Westerners', addressing the 'aftermath and ongoing realities' of colonialism and promoting 'cross-cultural understanding' (2006b: 3) As we have seen, although there were attempts to make connections with the living cultures of Hawaiians and other Pacific Islanders through performance events, photographic exhibitions and community consultations, there was far less engagement in the foundational curatorial processes, and a significant number of Hawaiians boycotted both exhibition and conference. With only one Pacific scholar ultimately presenting, the conference disappointed high hopes of cross-cultural dialogue. Moreover, the curatorial emphasis on the 'pristine', pre-contact nature of the objects tended to sequester them in a distant past, removed from the mixtures and impurities of cultural exchange, remote from the realm of contemporary indigenous knowledge and the politics of the present.

The curatorial intentions in Canberra were less a celebration of indigenous Oceanic creativity and connectivity, and more yet another celebration of the contested figure of Cook, not so much in his usual garb as simultaneously 'hero and villain', but rather as both a 'founding father' of Australia and an Oceanic ancestor. This twinning in the genealogy of Cook and the overwhelming emphasis on mutuality in material and cultural exchanges on his voyages blurred many of the hard questions about the reverberations of colonial power and knowledge in the present. These were addressed by some speakers in the associated symposium, Discovering Cook's Collections, but such critical views were barely evident 
in the exhibition itself. Moreover, the singular chance not only to see these objects in the 'Southern Hemisphere' but also to animate them through conversations with curators, scholars and cultural experts across the vastness of Oceania, including Pacific peoples resident in Australia, was, for the most part, missed.

Second, as we have seen, although the objects exhibited were almost identical in the exhibitions at the Honolulu Academy of Arts and the National Museum of Australia, the curatorial frames dramatically diverged. ${ }^{21}$ In Honolulu, the pristine Oceanic materiality of the objects was highlighted, devoid of both ethnographic and historical context. They were in Stéphane Martin's words 'nude' (Naumann 2006: 122). Bare of explanatory captions either about their indigenous creation or the context of their collection, they were thus more open to focused aesthetic attention, that effect cultivated by curators in most art galleries and some museums. But, despite being seen in an elite art gallery they were framed less as 'high art' and more as cultural treasures from the Pacific, and especially from Hawai' $i$, 'coming home'. This framing was patent in the promotional and publicity materials produced and in most of the newspaper and magazine articles about the exhibition (see, e.g. Carvalho 2006; Pang 2006). Many Hawaiian visitors were visibly moved, especially by the presence of Kū and there was much speculation in both the press and the electronic media that he might remain.

In Canberra, by contrast, the Oceanic creativity and connectivity of the objects was de-emphasised in favour of a focus on the European exploratory voyages. The exhibition space was rather darker and more crowded than the Honolulu venue. Although here the exhibition was mounted in a museum it did not display the objects as 'artefacts', nor surround them with copious ethnographic information. Rather, large pennants alongside the vitrines reproduced resounding phrases from the journals of Banks, Cook and the Forsters, describing the objects we were seeing, the peoples who made them and the contexts of their being collected or 'gifted' to the Europeans. The glass cases were often so engulfed by the English words of the voyagers that it was hard for the objects to speak to the viewer with their own Oceanic inflections.

21 Note, however, that the institutional appellation does not always mould curatorial style since although a 'museum', the MQB adopts a predominantly 'aesthetic' approach (see Jolly $2011 \mathrm{a}$ ). 
Moreover, both in the exhibition texts and in the catalogue there was a recurrent emphasis on the mutuality evinced in exchanges. Mutuality in the exchange of objects transmuted into the mutuality of unfamiliar peoples. Ultimately a warm bath of mutual cross-cultural exploration was brewed rather than a more critical sense of how such voyages of European exploration heralded the later colonisation of Oceania. A stress on the agency of Pacific peoples in the face of persisting narratives of colonialism as a fatal impact and of indigenous victimhood is welcome. But an opposite danger beckons when we prefer to see symmetry rather than asymmetry, parity rather than inequality and harmony rather than escalating violence in the wake of Cook's voyages. Rather than a sense of these objects coming 'home', as in Hawai' $i$, cosmopolitan cultural exchange between Europe and Oceania was highlighted and an optimistic genealogy for Australian multiculturalism plotted. This was most obvious in the transfiguration of Cook not just as an Enlightenment hero and founding father to the white nation of Australia but as an Oceanic ancestor: 'Tute, Kuki, Orono'.

Third, how far did these exhibitions succeed in reconnecting Oceanic objects with living Oceanic peoples, with their 'living culture' and with contemporary artistic traditions, as Ralph Regenvanu called for at the opening of the MQB in May 2005? Three years later at a conference in June 2008 in association with the Pacific Encounters exhibition at the MQB, Arapata Hakiwai, Mãori curator at Te Papa Tongarewa, suggested that the real treasures of Oceanic collections reside not in the objects themselves but in how they become subjects engendering new relationships. He stressed that this does not necessarily entail the repatriation of objects to establish reconnections with the descendants of their creators. Indeed, in some instances Māori iwi have rather decided that overseas museums are the 'custodians of choice' for their taonga and have seen virtual electronic repatriation as sufficient. Oceanic objects are thus better seen as subjects, reanimated as good cultural ambassadors (see Jolly 2011a).

Significantly at that same conference the Hawaiian curator from the Bishop Museum, Noelle Kahanu, and other delegates from Hawai' $i$ did not speak with such equanimity about Hawaiian objects as cultural ambassadors. Indeed, on seeing another manifestation of Kū, exhibited as part of the Pacific Encounters show at the MQB, Noelle Kahanu and Lilikalā Kame'eleihiwa wept and expressed a hope that all the overseas images of Kū might be united back in Hawai'i. But Kame'eleihiwa elaborated, she did not want them to come back home only to leave again soon after-likely a pointed reference to the evanescent passage of Kū through 
Honolulu in 2006. ${ }^{22}$ Thus, the way in which Oceanic peoples relate to the Oceanic 'objects' made by their ancestors is diverse and signals not just their past efficacy but their efficacy in the present, especially in contexts where they are animated subjects in political struggles. The relevant Mãori $i w i$ who are its custodians have decided that a valuable ancestral house, a whare tupuna embodying the ancestor Ruatepupuke should remain in the Field Museum in Chicago, but curators at Te Papa were equally adamant that the several mokomokai (heads chiselled with moko designs) in overseas museum collections, many collected in the context of the New Zealand land wars, should, as ancestral remains, come home for reburial. ${ }^{23}$ This was finally been agreed to by the French government in 2011, but other nations, institutions and individuals have yet to agree to such repatriations (see Jolly 2011a).

Yet, as we have seen, the moving of Oceanic objects 'back home' is no simple matter, and can animate not only the differences created across the beach of colonialism but differences between Oceanic peoples. The celebrated passage of the moving objects of the Cook/Forster collection back to Oceania was a grand act of cross-cultural diplomacy between Europe and Oceania. But their passage proved difficult in both Oceanic locations, of Honolulu and Canberra. In Hawai i $i$, some objects were clearly reanimated as subjects in the present, but in a way which reopened painful divisions between Hawaiian people. Their display articulated with other protracted and poignant disputes (notably the Kawaihae Caves case) and the broader conversations between all Hawaiians as to how best to look after the dead in the service of the living and how best to be custodians of the past in the service of the present. By contrast in Australia, no similar

22 The three images of Kū held by Göttingen, the Peabody and the Bishop Museum were briefly united at an exhibition at the Bishop Museum in Honolulu from 5 June-4 October 2010. But this was, as envisaged, an evanescent reunion (see Tengan 2016).

23 I thank the anonymous reviewers for The Contemporary Pacific for corrections and elaborations here. The whare tupuna (ancestral house) at the Field Museum embodying the ancestor Ruatepupuke is connected with the closely related hapu of Te Whānau a Ruataupare and Te Whānaua Te Aotawarirangi from Tokomaru Bay. Māori curators at Te Papa liaise with the appropriate Mãori iwi over such policy decisions. Moreover, there is a designated team of Mãori curators at Te Papa that deals with repatriation issues. It is important to see mokomōkai not just as individual ancestral remains but as embodying the ancestry of an entire iwi. Mokomōkai were usually collected by private individuals such as Horatio Robley (a British army officer and artist), often appropriated in the context of brutal land wars and traded with museum curators overseas. After the New Zealand government declined to buy Robley's collection, he sold it to the American Museum of Natural History. Hundreds of mokomökai still remain in public and private collections overseas and are the subject of ongoing demands for repatriation. 
passions were raised, perhaps because little was done to reconnect these objects with Oceanic peoples either in the islands or the diaspora, to reanimate them as subjects, as living presences in the present.

The project to create 'new' museums and galleries that realise postcolonial aspirations and truly respect the vital connections between living descendants and ancestral Oceanic creations is ongoing. This is not just the work of single exhibitions or solo curators but must be a foundational part of institutional curatorial practice. Te Papa Tongarewa, the National Museum of New Zealand, which opened in 1998, has long been at the forefront of this project, not just articulating but practising an ethos of partnership with Māori, Pacific Islanders and diverse communities. In Hawai $i$ there have been important advances over the last decade with the recreation of the Hawaiian and Pacific Halls at the Bishop Museum under the inspired vision of Noelle Kahanu and in 2012 the merger of the Honolulu Academy of Arts with the Contemporary Museum to form the Honolulu Museum of Art and the appointment of Healoaha Johnson as its first indigenous Hawaiian curator in 2015. There are also hopeful signs in Australia, Europe and North America. ${ }^{24}$ So perhaps we are witnessing an acceleration in reenvisioning the moving objects of Oceania as rather Oceanic subjects, propelling the practices of contemporary museums and galleries forward, toward a better future, not just in the region but globally.

\section{Acknowledgements}

This derives from the opening keynote lecture for the European Society for Oceanists' biennial conference held in Verona, Italy 10-12 July 2008. My heartfelt thanks to Anna Paini and Elisabetta Gnecchi-Ruscone for their welcome invitation to deliver this in Verona and for their hard work in translation for the Italian version published in Paini and Gnecchi-Ruscone 2011. In editing that spoken lecture I have tried to retain some of the

24 In a similar period to the exhibitions discussed here were two exhibitions curated in the UKPasifika Styles at the Cambridge Museum of Archaeology and Anthropology (CMAA) from 20062008 (Raymond and Salmond 2008) and Pacific Encounters at the Sainsbury Centre at the University of East Anglia and then MQB in 2008 (Hooper 2006; Jacobs 2009). These were distinctive in that the former focused on contemporary Pacific artists, while the latter incorporated contemporary art alongside earlier Oceanic creations. The animation of objects through the presence of Pacific peoples and artists in museum contexts and community collaborations has been pursued by Nicholas Thomas, currently director of CMMA, and Lissant Bolton, keeper at the British Museum. Similar hopes are foregrounded in the current Pacific Presences project at CMAA. 
voice of the oral original, but this final English text differs in significant ways. The section on the MQB became the subject of a related paper (Jolly 2011a) and a written but unread section on the Australian Museum in Sydney has been omitted to enhance the focus on the exhibitions of the Cook/Forster collection. The final epilogue on the artist Fiona Hall which proved popular in the oral presentation has been deleted, hopefully to re-emerge in future writing on her work and especially her presentation at the Australian Pavilion in the Venice Biennale of 2015, restaged at the National Gallery of Australia from May to July 2016. The very extensive footnotes have been pared back, but are more extensive than in the journal version. Given the time elapsed since that lecture, I have updated and revised a little. Many thanks to James Clifford, Robert Foster, Elfriede Hermann, Chris Ballard, Geremie Barmé and Michelle Antoinette for comments and criticisms at several stages of writing and revision. I warmly thank Michelle for superb assistance with proofreading and with the compilation, reproduction and permissions for images both for the conference presentation and for the Italian publication. More recently many thanks to Carolyn Brewer for stellar editing assistance, and Nicholas Mortimer for checks for continuing online references and image permissions. A shorter English version has recently appeared in The Contemporary Pacific 28(2): 281-314 and I thank the editors of that journal for permission to republish this slightly longer version here. All remaining errors and infelicities are mine.

\section{References}

Alpers, Svetlana. 1991. 'The museum as a way of seeing'. In Exhibiting Cultures: The Poetics and Politics of Museum Display, ed. Ivan Karp and Steven D. Lavine, pp. 25-42. Washington DC: Smithsonian Institution Press.

Andrade, Ivy Hali'imaile. 2007. 'Review of Life in the Pacific of the 1700s'. The Contemporary Pacific 19(1): 341-42.

Ballard, Chris. 2006. 'Tied to the cabinet of curiosities'. The Times Literary Supplement, 15 September, 5938: 20.

Blumenbach, Johann Friedrich. 1775. De Generis Humani Varietate Nativa. Goettingae: Frid. Andr. Rosenbuschii. 
Bolton, Lissant. 2009. 'Brushed with fame: Museological investments in the Cook voyage collections'. In Discovering Cook's Collections, ed. Michelle Hetherington and Howard Morphy, pp. 78-91. Canberra: National Museum of Australia.

— 2006. 'The museum as cultural agent: The Vanuatu Cultural Centre extension worker program'. In South Pacific Museums: Experiments in Culture, ed. Chris Healy and Andrea Witcomb, pp. 13.1-13.13. Melbourne: Monash University ePress.

Carvalho, Marie. 2006. 'Objects tell Pacific peoples' stories'. Honolulu Advertiser, 9 April.

Clifford, James. 2014. 'Art and ethnography'. Paper presented at Macquarie University Anthropology Seminar, Sydney. 23 October.

—. 2007. 'Quai Branly in process'. October 120 (Spring): 3-23. Republished in edited form in Le debat: Le moment du Quai Branly 147: 29-39.

Coote, Jeremy. 2004. Curiosities from the Endeavour: A Forgotten Collection - Pacific Artefacts given by Joseph Banks to Christ Church, Oxford, after the First Voyage. Whitby: Captain Cook Memorial Museum.

Dening, Greg. 2009. 'Looking across the beach - both ways'. In Discovering Cook's Collections, ed. Michelle Hetherington and Howard Morphy, pp. 11-24. Canberra: National Museum of Australia.

Di Piazza Anne and Erik Pearthree. 2007. 'A new reading of Tupaia's chart'. Journal of the Polynesian Society 116(3): 321-40.

Drake, Maile T. 2007. 'Review of Life in the Pacific of the 1700s'. The Contemporary Pacific 19(1): 342-43. doi.org/10.1353/ cp.2007.0009.

Fleck, Robert and Adrienne L. Kaeppler (eds). 2009. James Cook und die Entdeckung der SüdseelJames Cook and the Exploration of the Pacific. Bonn: Kunst-und Ausstellungshalle der Bundesrepublik Deutchsland; English version, London: Thames and Hudson.

Forster, George. 1777. A Voyage Round the World in His Britannic Majesty's Sloop Resolution. London: B. White. 
Forster, George. 2000 [1777]. A Voyage Round the World, vols 1 and 2, ed. Nicholas Thomas and Oliver Berghof. Honolulu: University of Hawai'i Press.

Forster, Johann Reinhold. 1778. Observations Made During a Voyage Round the World on Physical Geography, Natural History and Ethic Philosophy. London: G. Robinson.

—_. 1996 [1778]. Observations Made During a Voyage Round the World, on Physical Geography, Natural History and Ethic Philosophy, new edition, ed. Nicholas Thomas, Harriet Guest and Michael Dettelbach. Honolulu: University of Hawai'i Press.

Gell, Alfred. 1998. Art and Agency: An Anthropological Theory. Oxford: Clarendon Press.

Hau'ofa, Epeli. 2008. We Are the Ocean: Selected Works. Honolulu: University of Hawai'i Press.

Hauser-Schäublin, Brigitta and Gundolf Krüger. 2006a. Cook's Pacific Encounters, Cook/Forster Collection: Pacific Cultural Heritage. National Museum of Australia website. Online: www.nma.gov.au/ online_features/cook_forster (accessed 5 August 2016).

- - 2006b. 'Introduction'. In Life in the Pacific in the 1700s: The Cook/Forster Collection of the Georg-August University of Göttingen, ed. Stephen Little and Peter Ruthenberg. Vol. 2, European Research, Traditions and Perspectives, co-ed. Brigitta Hauser-Schäublin and Gundolf Krüger, pp. 21-35. Honolulu: Honolulu Academy of Arts.

—_. 2006c. 'Pacific cultural heritage: The Göttingen Cook Forster collection'. In Cook's Pacific Encounters: The Cook/Forster Collection of the Georg-August University of Göttingen, pp. 15-27. Canberra: National Museum of Australia.

Hauser-Schäublin, Brigitta and Gundolf Krüger (eds). 1998. James Cook: Gifts and Treasures from the South Seas. Munich and New York: Prestel.

Hermann, Elfriede (ed.). 2011. Changing Contexts, Shifting Meanings: Transformations of Cultural Traditions in Oceania. Honolulu: University of Hawai'i Press and Honolulu Academy of Arts.

Hetherington, Michelle and Howard Morphy (eds). 2009. Discovering Cook's Collections. Canberra: National Museum of Australia. 
Hooper, Steven. 2006. Pacific Encounters: Art \& Divinity in Polynesia 1760-1860. Norwich: Sainsbury Centre for Visual Arts and British Museum Press.

Jacobs, Karen (ed.). 2009. Encounters with Polynesia: Exhibiting the Past in the Present. Special issue of The Journal of Museum Ethnography, 21.

Johnson, Greg. 2009. 'Social lives of the dead: Contestation and continuities in the Hawaiian repatriation context'. In Culture and Belonging in Divided Societies: Contestation and Symbolic Landscapes, ed. Marc Ross, pp. 45-67. Philadelphia: University of Pennsylvania Press. doi.org/10.9783/9780812203509.45.

- 2007. Sacred Claims: Repatriation and Living Tradition. Charlottesville and London: University of Virginia Press.

Jolly, Margaret. 2014. 'Animatimg Atua: In the presence of Polynesian gods'. Art Monthly Australia April: 34-39.

—_. 2011a. 'Becoming a "new" Museum: Contesting Oceanic visions at Musée du Quai Branly'. The Contemporary Pacific 23(1):108-39.

_ 2011b. 'Beyond the beach: Re-articulating the limen in Oceanic pasts, presents and futures'. In Changing Contexts, Shifting Meanings: Transformations of Cultural Traditions in Oceania, ed. Elfriede Hermann, pp. 56-73. Honolulu: University of Hawai'i Press and Honolulu Academy of Arts.

- 2009a. 'Revisioning gender and sexuality on Cook's voyages in the Pacific'. In James Cook und die Entdeckung der Sudseel James Cook and the Exploration of the Pacific, ed. Robert Fleck and Adrienne L. Kaeppler, pp. 98-102. Bonn: Kunst-und Ausstellungshalle der Bundesrepublik Deutchsland; English version, London: Thames and Hudson.

—. 2009b. 'The sediment of voyages: Re-membering Quirós, Bougainville and Cook in Vanuatu'. In Oceanic Encounters: Exchange, Desire, Violence, ed. Margaret Jolly, Serge Tcherkézoff and Darrell Tryon, pp. 57-111. Canberra: ANU E-Press. Online: press.anu.edu. au/publications/oceanic-encounters (accessed 5 August 2016). 
2009c. 'Revisioning gender and sexuality on Cook's voyages in the Pacific'. In James Cook und die Entdeckung der Sudseel James Cook and the Exploration of the Pacific, ed. Robert Fleck and Adrienne L. Kaeppler, pp. 98-102. Bonn: Kunst-und Ausstellungshalle der Bundesrepublik Deutchsland; English version, London: Thames and Hudson.

—_. 2008. 'The south in Southern Theory: Antipodean reflections on the Pacific'. Australian Humanities Review 44(March): 75-100.

—_. 2007a. 'Imagining Oceania: Indigenous and foreign representations of a sea of islands'. The Contemporary Pacific 19(2): 508-45. doi. org/10.1353/cp.2007.0054.

__. 2007b. 'Unsettling memories: Commemorating "discoverers" in Australia and Vanuatu in 2006'. In Fernández de Quirós et le Vanuatu. Décourverte mutuelle et historiographie d'un acte fondateur 1606, ed. Frédéric Angleviel, pp. 197-219. GROCH Nouméa with assistance of the European Union, République Française, Vanuatu Government and Vanuatu National Cultural Council. Port Vila: Sun Productions.

__. 1992. "Ill-natured comparisons": Racism and relativism in European representations of ni-Vanuatu from Cook's second voyage'. History and Anthropology 5(3-4): 331-64.

Jolly, Margaret with Serge Tcherkézoff. 2009. 'Oceanic encounters: A prelude'. In Oceanic Encounters: Exchange, Desire, Violence, ed. Margaret Jolly, Serge Tcherkézoff and Darrell Tryon, pp. 1-36. Canberra: ANU E Press. Online: press.anu.edu.au/publications/ oceanic-encounters (accessed 5 August 2016).

Kaeppler, Adrienne L. 2009a. “"To attempt some new discoveries in that vast unknown tract": Rediscovering the Forster collections from Cook's Second Pacific voyage'. In Discovering Cook's Collections, ed. Michelle Hetherington and Howard Morphy, pp. 58-77. Canberra: National Museum of Australia.

- 2009b. 'Enlightened encounters in the unknown Pacific'. In James Cook und die Entdeckung der SudseelJames Cook and the Exploration of the Pacific, ed. Robert Fleck and Adrienne L. Kaeppler, pp. 88-92. Bonn: Kunst-und Ausstellungshalle der Bundesrepublik Deutchsland; English version London: Thames and Hudson. 
— 2008. 'Exhibiting Cook's voyages in the Leverian Museum and today'. Paper presented to symposium Exhibiting Polynesia: Past, Present and Future, 17-18 June, Musée du Quai Branly, Paris.

- 2006. 'Life in the Pacific in the 1700s and today'. In Life in the Pacific in the 1700s: The Cook/Forster Collection of the Georg-August University of Göttingen, ed. Stephen Little and Peter Ruthenberg. Vol. 2, European Research, Traditions and Perspectives, co-ed. Brigitta Hauser-Schäublin and Gundolf Krüger, pp. 8-19. Honolulu: Honolulu Academy of Arts.

- 1998. 'The Göttingen collection in an international context'. In James Cook: Gifts and Treasures from the South Seas, ed. Brigitta Hauser-Schäublin and Gundolf Krüger, pp. 86-93. Munich and New York: Prestel.

- 1988. 'Pacific culture history and European voyages'. In Terra Australis: The Furthest Shore, ed. William Eisler and Bernard Smith, pp. 141-46. Sydney: Art Gallery of New South Wales.

- 1979. 'Tracing the history of Cook voyage artifacts in the Museum of Mankind'. The British Museum Yearbook. British Museum London, vol 3: 167-97.

- 1978a. Artificial Curiosities: An Exposition of Native Manufactures Collected on the Three Pacific Voyages of Captain James Cook, RN. Bernice P. Bishop Museum Special Publication 65. Honolulu: Bishop Museum Press.

- 1978b. Cook Voyage Artifacts in Leningrad, Berne and Florence Museums. Honolulu: Bishop Museum Press.

Keane, Webb. 2007. Christian Moderns: Freedom and Fetish in the Mission Encounters. Berkeley: University of California Press.

Kimmelman, Michael. 2006. 'A heart of darkness in the city of light'. New York Times, 2 July. Online: nytimes.com/2006/07/02/arts/ design/02kimm.html (accessed 4 April 2013).

Kosasa, Karen. 2007. 'Review of Life in the Pacific of the 1700s'. The Contemporary Pacific 19(1): 344-45. doi.org/10.1353/ cp.2007.0020. 
Latour, Bruno. 1993 [1991]. We Have Never Been Modern, trans. Catherine Porter. Cambridge, MA: Harvard University Press.

Little, Stephen. 2006a. Press Release for exhibition Life in the Pacific of the 1700s, Exhibition Guide. Honolulu: Honolulu Academy of Arts, 26 January.

—_. 2006b. 'Foreword'. In Life in the Pacific of the 1700s, Exhibition Guide, ed. Stephen Little and Peter Ruthenberg. Honolulu: Honolulu Academy of Arts.

Little, Stephen and Peter Ruthenberg (eds). 2006a. Life in the Pacific of the 1700s, Exhibition Guide. Honolulu: Honolulu Academy of Arts.

—_ (eds). 2006b. Life in the Pacific in the 1700s: The Cook/Forster Collection of the Georg-August University of Göttingen, vol. 1. In Artifacts from Life in the Pacific in the 1700s: The Cook/Forster Collection of the Georg-August University of Göttingen, ed. Stephen Little and Peter Ruthenberg. Honolulu: Honolulu Academy of Arts.

MacDonald, Sharon. 2007. 'Review of Kylie Message 2006. New Museums and the Making of Culture. In reCollections, Journal of the National Museum of Australia 2(2). Online: recollections.nma.gov.au/ issues/vol_2_no2/book_reviews/new_museums_and_the_making of_culture/ (accessed 4 April 2013).

Macintyre, Stuart and Anna Clark. 2004. The History Wars, 2nd edition. Melbourne: Melbourne University Press.

Mellor, Doreen. 2009. 'Cook, his mission and Indigenous Australia: A perspective on consequence'. In Discovering Cook's Collections, ed. Michelle Hetherington and Howard Morphy, pp. 112-26. Canberra: National Museum of Australia.

Message, Kylie. 2006. New Museums and the Making of Culture. Oxford: Berg.

Morton, Craddock. 2006. 'Introduction'. In Cook's Pacific Encounters: The Cook/Forster Collection of the Georg-August University of Göttingen, pp. xi-xiv. Canberra: National Museum of Australia. doi.org/10.1017/ ccol0521826047.001. 
National Museum of Australia (NMA). 2006. Cook's Pacific Encounters: The Cook/Forster Collection of the Georg-August University of Göttingen. Canberra: National Museum of Australia.

Naumann, Peter. 2006. 'Making a museum: "It is making theater, not writing theory"'. An interview with Stéphane Martin, PrésidentDirecteur General, Musée du Quai Branly. Journal of Museum Anthropology 29(2): 118-27. doi.org/10.1525/mua.2006.29.2.118.

Newell, Jennifer. 2010. Trading Nature: Tahitians, Europeans and Ecological Exchange. Honolulu: University of Hawai'i Press. doi.org/10.21313/ hawaii/9780824832810.001.0001.

- 2006. 'Collecting from the collectors: Pacific islanders and the spoils of Europe'. In Cook's Pacific Encounters: The Cook/Forster Collection of the Georg-August University of Göttingen, pp. 29-45. Canberra: National Museum of Australia.

Nugent, Maria. 2009. Captain Cook Was Here. Cambridge: Cambridge University Press.

Obeyesekere, Gananath. 1992. The Apotheosis of Captain Cook: European Mythmaking in the Pacific. Princeton, NJ: Princeton University Press; Honolulu: Bishop Museum Press.

Office of Hawaiian Affairs Newsletter. 2006. Discussion Forum Perspectives on the Kawaihae burial controversy. January 2006: 7.

Paini, Anna and Elisabetta Gnecchi-Ruscone (eds). 2011. Putting People First: Dialogo interculturale immaginado il futuro in Oceania. Special issue of La Ricerca Folklorica 63 (April).

Pang, Gordon Y.K. 2006. 'Gifts to Cook come back to Pacific'. Honolulu Advertiser, 4 February. Online: the.honoluluadvertiser.com/ article/2006/Feb/04/In/FP602040330.html (accessed 1 March 2016).

Price, Sally. 2007. Paris Primitive: Jacques Chirac's Museum on the Quai Branly. Chicago: University of Chicago Press.

Raymond, Rosanna and Amiria Salmond (eds). 2008. Pasifika Styles: Artists inside the Museum. Cambridge: University of Cambridge Museum of Archaeology and Anthropology. 
Sahlins, Marshall. 1995. How 'Natives' Think. About Captain Cook, For Example. Chicago: University of Chicago Press. doi.org/10.7208/ chicago/9780226733715.001.0001.

__ 1989. 'Captain Cook at Hawaii'. Journal of the Polynesian Society 98(4): 371-423.

—_. 1985. Islands of History. Chicago: University of Chicago Press.

- 1982. 'The apotheosis of Captain Cook'. In Between Belief and Transgression: Structuralist Essays in Religion, History and Myth, ed. Michel Izard and Pierre Smith, pp. 73-102. Chicago: University of Chicago Press.

Salmond, Anne. 2003. The Trial of the Cannibal Dog: Captain Cook in the South Seas. London: Allen Lane, Penguin Books.

Smith, Bernard. 1992. 'Cook's posthumous reputation'. In Imagining the Pacific: In the Wake of the Cook Voyages, pp. 225-40. Carlton: Melbourne University Press at the Miegunyah Press.

—_. 1985 [1960]. European Vision and the South Pacific, 1768-1850, 2nd edition. Sydney: Harper \& Row.

Stillman, Amy Ku'uleialoha. n.d. 'On academic voyages of encounter'. Ms in author's collection.

Strathern, Marilyn. 1988. The Gender of the Gift: Problems with Women and Problems with Society in Melanesia. Berkeley: University of California Press. doi.org/10.1525/california/9780520064232.001.0001.

Tapsell, Paul. 2009. 'Footprints in the sand: Banks's Māori collection, Cook's first voyage 1768-71'. In Discovering Cook's Collections, ed. Michelle Hetherington and Howard Morphy, pp. 92-111. Canberra: National Museum of Australia.

Tengan, Ty P Kāwika. 2016. 'The mana of Kū: Indigenous nationhood, masculinity and authority in Hawai' $i$ '. In New Mana: Transformations of a Classic Concept in Pacific Languages and Cultures, ed. Matt Tomlinson and Ty P Kāwika Tengan, pp. 55-75. Canberra: ANU Press. Online: press-files.anu.edu.au/downloads/press/p343683/pdf/ ch02.pdf (accessed 5 August 2016). 
Thomas, Nicholas. 2003. Discoveries: the Voyages of Captain Cook. London: Allen Lane, Penguin Books.

1997. 'Liberty and license: New Zealand societies in Cook voyage anthropology'. In In Oceania. Visions, Artifacts, Histories, pp. 71-92. Durham and London: Duke University Press.

- 1996. "On the varieties of the human species": Forster's comparative ethnology'. Introduction to new edition of J.R. Forster, Observations Made During a Voyage Round the World on Physical Geography, Natural History and Ethic Philosophy, pp. xxiii-xl. Honolulu: University of Hawai'i Press.

—. 1995. Oceanic Art. London: Thames and Hudson.

- 1994. 'Licensed curiosity: Cook's Pacific voyages'. In The Cultures of Collecting, ed. John Elsner and Roger Cardinal, pp. 116-36, 28182. London: Reaktion Books.

Wong, Sterling Kini. 2006a. 'Burial group resists court order'. In Office of Hawaiian Affairs Newsletter, January 2006: 6.

—. 2006b. 'Burial dispute goes to mediation'. In Office of Hawaiian Affairs Newsletter, February 2006: 9.

—. 2006c. 'Forbes Cave objects reportedly returned to Bishop Museum'. In Office of Hawaiian Affairs Newsletter, October 2006: 8. 
This text is taken from Tides of Innovation in Oceania: Value, materiality and place, edited by Elisabetta Gnecchi-Ruscone and Anna Paini, published 2017 by ANU Press, The Australian National University,

Canberra, Australia. 